\title{
Update of Emerinopathies' clinical-genetic spectrum: the French network experience
}

\author{
France Leturcq ${ }^{*}$, Rabah Ben Yaou* \\ From 1st French-Italian meeting on laminopathies and other nuclear envelope-related diseases \\ Marseille, France. 15-16 January 2015
}

Emerinopathies include diseases caused by EMD gene mutations localized on chromosome $\mathrm{X}$ and encoding emerin, an integral protein of the nuclear envelope. The most frequent emerinopathy is the X-linked EmeryDreifuss muscular dystrophy (X-EDMD) that was first reported in the 60ths by Emery and Dreifuss [1]. The disease is characterized by muscle weakness and wasting usually with a humeroperoneal distribution in the first stages, early joint contractures involving Achilles tendons, elbows, neck and the whole spine, and cardiac involvement featuring conduction defects, arrhythmias, subsequent cardiomyopathy (usually dilated) and frequently responsible of sudden death. Bione et al. [2] identified the first mutations of $E M D$ gene encoding emerin to be responsible of X-EDMD. These mutations usually lead to absence or reduced level of emerin in different tissues of affected males including skeletal muscle, skin, oral mucosa cells and lymphocytes as it is demonstrated by immunocytochemical and histochemical methods $[3,4]$. Female carriers exhibit mosaic expression patterns with usually normal emerin amounts [3]. These methods may thus be used in the diagnostic strategy of X-EDMD prior to $E M D$ gene analysis.

In a recent study (unpublished work from the French network and LBGM) aiming to assess the diagnostic utility of emerin study by western blot on lymphoblastoïd cell lines, we looked at $E M D$ mutation rate observed in a cohort of 269 male and female patients with variable emerin amounts. In male patients, absence or severe reduction of emerin $(<5 \%)$ lead to $E M D$ mutation identification in all cases, while moderate emerin amount reduction revealed $E M D$ mutation in $75 \%$ of the patients. Interestingly, in all cases where emerin amounts were considered as normal, no EMD mutations were found. In

\footnotetext{
* Correspondence: france.leturcq@inserm.fr; r.benyaou@institut-myologie.org AP-HP, Groupe Hospitalier Cochin-Broca-Hôtel Dieu, Laboratoire de biochimie et génétique moléculaire (LBGM), Paris, France
}

female cases, all cases with emerin moderate or severe reduction harbored EMD mutation. When emerin is normal, $E M D$ mutation was found in $58 \%$ of female cases. These results suggest that a diagnostic rate of $100 \%$ may be reached if emerin study by western blot is performed prior to EMD gene screening in male patients. Moreover, emerin gene mutations have been rarely observed in rare cases of isolated cardiac disease [5,6] and limb girdle muscular dystrophies with cardiac disease and without joint contractures $[7,8]$.

We reported of a new family with an unusual type of $\mathrm{X}$-linked fatal isolated cardiac disease. The family included 9 affected male subjects with early death within the $4^{\text {th }}$ to $6^{\text {th }}$ decades and suffering from dilated cardiomyopathy (DCM) with arrhythmias requiring ICD implantation and or heart transplantation in some cases. Two surviving brothers were assessed. The first brother had DCM since 49 years old, ICD implantation at 51, additional Pacemaker at 52. His neurological assessment as well as CPK and EMG were normal at 53. His young brother had also DCM since 38 years old and his neurological assessment was normal at 45 . Muscle biopsy performed in the oldest brother was considered as normal. Emerin protein analysis on muscle by Western blot using MANEM8 antibodies showed normal amounts while emerin immunostaining studies on muscle cryosections using NCL-Emerin antibodies showed complete absence of emerin. Subsequent $E M D$ gene analysis revealed a missense mutation within exon 1.

By using the UMD-EMD locus specific database (http://www.umd.be/EMD/) gathering all published EMD gene mutations as well as those found in LBGM (more than 200 families), authors looked at EMD mutation spectrum. It was found that truncating mutations leading to absence or highly decreased emerin represent more than $65 \%$ of probands, while non-truncating mutations, including missense ones and leading to either absence or 
abnormal emerin, represents $21,5 \%$ of probands. The remaining probands (13.5\%) carry intronic mutations with variable emerin amounts according to alternative splicing. There are no clear phenotype/genotype correlations due to high intra- and inter-familial variability. Truncating mutations may lead to classical forms of EDMD as well as severe forms with early ambulation loss and moderate forms with benign skeletal muscle involvement.

Published: 11 November 2015

\section{References}

1. Emery $A E$, Dreifuss FE: Unusual type of benign $x$-linked muscular dystrophy. Journal of neurology, neurosurgery, and psychiatry 1966 29(4):338-42.

2. Bione $S$, Maestrini $E$, Rivella S, Mancini M, Regis S, Romeo G, et al: Identification of a novel X-linked gene responsible for Emery-Dreifuss muscular dystrophy. Nature genetics 1994, 8(4):323-7.

3. Manilal S, Recan D, Sewry CA, Hoeltzenbein M, Llense S, Leturcq F, et al: Mutations in Emery-Dreifuss muscular dystrophy and their effects on emerin protein expression. Human molecular genetics 1998, 7(5):855-64.

4. Nagano A, Koga R, Ogawa M, Kurano Y, Kawada J, Okada R, et al: Emerin deficiency at the nuclear membrane in patients with Emery-Dreifuss muscular dystrophy. Nature genetics 1996, 12(3):254-9.

5. Ben Yaou R, Toutain A, Arimura T, Demay L, Massart C, Peccate C, et al: Multitissular involvement in a family with $L M N A$ and EMD mutations: Role of digenic mechanism? Neurology 2007, 68(22):1883-94

6. Karst ML, Herron KJ, Olson TM: X-linked nonsyndromic sinus node dysfunction and atrial fibrillation caused by emerin mutation. Journal of cardiovascular electrophysiology 2008, 19(5):510-5.

7. Muntoni F, Lichtarowicz-Krynska EJ, Sewry CA, Manilal S, Recan D, Llense S, et al: Early presentation of X-linked Emery-Dreifuss muscular dystrophy resembling limb-girdle muscular dystrophy. Neuromuscular disorders: NMD 1998, 8(2):72-6.

8. Ura S, Hayashi YK, Goto K, Astejada MN, Murakami T, Nagato M, et al: Limbgirdle muscular dystrophy due to emerin gene mutations. Archives of neurology 2007, 64(7):1038-41.

doi:10.1186/1750-1172-10-S2-O16

Cite this article as: Leturcq and Ben Yaou: Update of Emerinopathies' clinical-genetic spectrum: the French network experience. Orphanet Journal of Rare Diseases 2015 10(Suppl 2):O16.

\section{Submit your next manuscript to BioMed Central} and take full advantage of:

- Convenient online submission

- Thorough peer review

- No space constraints or color figure charges

- Immediate publication on acceptance

- Inclusion in PubMed, CAS, Scopus and Google Scholar

- Research which is freely available for redistribution

Submit your manuscript at www.biomedcentral.com/submit
C Biomed Central 